\title{
ANALISIS PELAKSANAAN KESELAMATANN DAN KESEHATAN KERJA (K3) DI BAGIAN PENDAFTARAN KLINIK PRATAMA GREEN CARE KOTA BANDUNG DI MASA PANDEMI COVID-19
}

\author{
Reno Ramadhan ${ }^{1}, M$ Taofik Hidayat ${ }^{2}$, Irda Sari ${ }^{3}$ \\ Politeknik Piksi Ganesha Bandung, Indonesia \\ reno.ramadhan78@gmail.com ${ }^{1}$,piksi.mtaofikhidayat.18403211@gmail.com², \\ irdasari13@gmail.com ${ }^{3}$
}

Received: 19-08-2021

Revised : 13-11-2021

Accepted: 18-11-2021

\begin{abstract}
Abstrak
Latar Belakang: Petugas pendaftaran tidak bisa lepas dari potensi-potensi berbahaya yang bisa menyebabkan kecelakaan kerja.
\end{abstract}

Tujuan: Penelitian ini bertujuan untuk mengetahui kepatuhan pegawai rekam medis bagian pendaftaran di klinik Pratama green care terhadap penerapan Standar Operasional Prosedur (SOP) Keselamatann dan Kesehatan Kerja (K3).

Metode: Penelitian ini menggunakan jenis penelitian metode kualitatif dengan pendekatan deskriptif. Subjek yang digunakan penelitian ini adalah petugas rekam medis di bagian pendaftaran Klinik Pratama Green care. Teknik pengumpulan data yang digunakan dalam penelitian berupa angket terbuka atau kuesioner dan wawancara semi struktur. Hasil: Berdasarkan hasil penelitian yang dilakukan didapatkan pengetahuan petugas pendaftaran akan SOP K3 di masa pandemi COVID-19 sudah mengetahui semua dan dalam pelaksanaan nya salah satu petugas masih kurang disiplin. Kurang nya pengawasan dari pihak manajemen klinik.

Kesimpulan: Belum ada nya pelatihan dan pendidikan kepada petugas untuk pelaksanaan yang baik dan benar. Untuk penanganannya sudah berjalan dengan baik.

Kata kunci: keselamatann dan kesehatan kerja; petugas pendaftaran; pandemi COVID-19.

\begin{abstract}
Background: Registration officers cannot be separated from dangerous potentials that can cause work accidents. Objective: This study aims to determine the compliance of medical record employees at the registration section at the Pratama green care clinic to the application of Standard Operating Procedures (SOP) for Occupational Safety and Health (K3).

Methods: This study uses a qualitative research type with a descriptive approach. The subjects used in this study were medical record officers at the registration section of the Pratama Green care Clinic. The data collection techniques
\end{abstract}


used in the study were open questionnaires or

questionnaires and semi-structured interviews.

Results: Based on the results of the research conducted, it was found that the knowledge of the registration officer about the K3 SOP during the COVID-19 pandemic already knew everything and in practice one of the officers was still lacking in discipline. Lack of supervision from the clinical management.

Conclusion: There has been no training and education for officers for good and correct implementation. The handling has gone well.

Keywords: occupational safety and health; officer registration; COVID-19 pandemic.

*Correspondent Author: M Taofik Hidayat

Email: piksi.mtaofikhidayat.18403211@gmail.com

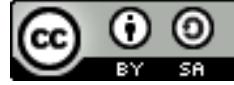

\section{PENDAHULUAN}

Pelayanan kesehatan terhadap masyarakat tidak hanya diperoleh di rumah sakit dan puskesmas, tapi juga dapat diperoleh di klinik (Nugrahanto, 2018). Klinik juga harus mempunyai fungsi pelayanan medis, pelayanan keperawatan, pelayanan gawat darurat, administrasi dan manajemen dan rekam medis untuk menunjang dan meningkatkan mutu pelayanan terhadap pasien sebagai konsumen. Klinik adalah fasilitas pelayanan kesehatan yang menyelenggarakan pelayanan kesehatan perorangan yang menyediakan pelayanan medis dasar dan/atau spesialistik. Berdasarkan jenis pelayanan, Klinik dibagi menjadi Klinik Pratama Klinik Utama. Klinik pratama merupakan klinik yang menyelenggarakan pelayanan medik dasar baik umum maupun khusus (Menkes, 2011).

Rekam medis merupakan salah satu komponen yang menunjang sistem administrasi di pelayanan kesehatan. Rekam Medis adalah berkas yang berisikan catatan dan dokumen tentang identitas pasien, pemeriksaan, pengobatan, tindakan dan pelayanan lain kepada pasien rawat jalan, rawat inap maupun gawat darurat di suatu pelayanan kesehatan (Menkes, 2008). Mengingat bahwa seluruh kegiatan rekam medis diselenggarakan oleh sumber daya manusia yang secara langsung merupakan subjek yang paling berperan dalam kelancaran berbagai proses, maka kesehatan dan keselamatann kerja pegawai di bagian rekam medis harus mendapat perhatian yang cukup serius.

Keselamatann dan Kesehatan Kerja (K3) merupakan sistem perlindungan tenaga kerja (Ivana, 2014). Keselamatann dan Kesehatan Kerja (K3) di pelayanan kesehatan harus dapat menjamin kenyamanan karyawan saat bekerja untuk mencegah tingkat kecelakaan dan penyakit akibat kerja (Djatmiko, 2016). Pelaksanaan Keselamatann dan Kesehatan Kerja (K3) adalah salah satu bentuk upaya untuk menciptakan tempat kerja yang aman, sehat, bebas dari pencemaran lingkungan, sehingga dapat mengurangi dan atau bebas dari kecelakan kerja dan penyakit akibat kerja yang pada akhirnya dapat meningkatkan efisiensi dan produktivita kerja (Salawati, 2015).

Menurut (Anizar \& Kes, 2009), kecelakaan adalah suatu kejadian yang tidak diharapkan dan tidak diinginkan yang mengganggu proses suatu kegiatan yang telah diatur. Dalam proses terjadinya kecelakaan berhubungan dengan empat unsur produksi yaitu People, Equipment, Materials, Environment, yang saling berinteraksi dan bersama-sama menghasilkan suatu produk atau jasa. Kecelakaan dapat terjadi dalam proses interaksi yaitu ketika terjadi kontak antara manusia dengan alat, bahan dan lingkungan Kecelakaan dapat terjadi karena kondisi peralatan atau material yang buruk atau berbahaya. Kecelakaan juga Analisis Pelaksanaan Keselamatann dan Kesehatan Kerja (K3) di Bagian Pendaftaran Klinik Pratama Green care di Masa Pandemi COVID-19 
dapat dipicu oleh kondisi lingkungan kerja yang tidak aman seperti ventilasi, pencahayaan, kebisingan atau suhu yang tidak aman melebihi ambang batas. Selain itu, kecelakaan juga dapat berasal dari manusia yang melakukan aktivitas di tempat kerja dan menangani alat atau bahan, termasuk di bagian penyimpanan rekam medis atau di bagian pendaftaran pasien (Irwansyah, 2017).

Salah satu kegiatan pada unit rekam medis adalah pendaftaran. Dalam pelayanan Rekam Medis petugas pendaftaran memiliki peran penting, diantaranya adalah mendaftarkan pasien yang datang berobat dan mencatat atau mengisi register di buku kunjungan Klinik. Pada saat melakukan tugasnya, petugas pendaftaran tidak bisa lepas dari potensi-potensi berbahaya yang bisa menyebabkan kecelakaan kerja. Contoh kecelakaan kerja yang dapat terjadi di bagian pendaftaran adalah terpapar bakteri dan virus seperti yang sedang marak saat ini yaitu virus COVID-19 (Mukti, 2021).

Severe acute respiratory syndrome coronavirus 2 (SARS-CoV-2) yang lebih dikenal dengan nama virus Corona adalah jenis baru dari coronavirus yang menular ke manusia (Lai, 2020). Virus corona jenis baru ini memiliki tingkat penularan yang tinggi sehingga telah menyebar secara global di negara-negara lain termasuk indonesia. COVID19 memberikan dampak yang besar bagi kehidupan masyarakat di berbagai bidang salah satu contohnya dalam bidang kesehatan (Korompot, 2020). Pengaruh pandemi COVID-19 dalam bidang kesehatan yaitu tingkat kesehatan menurun karena banyak yang terpapar COVID-19. Tingkat penularan dan infeksi COVID-19 di antara tenaga kesehatan lainnya juga tinggi, termasuk di bagian pendaftaran. Selama Pandemi COVID-19 juga memberikan perubahan tata kerja baru, sehingga juga diperlukan strategi pengendalian baru dalam penerapan keselamatann dan Kesehatan Kerja (K3) di tempat kerja di masa pandemi (Respati \& Rathomi, 2020).

Dalam keputusan Direktur Jenderal Pembinaan Pengawasan Ketenagakerjaan dan Keselamatann dan Kesehatan kerja nomor 5/151/AS.02/XI/2020 tentang Pedoman Keselamatann dan Kesehatan Kerja (K3) Pelaksanaan Pemeriksaan Kesehatan Tenaga Kerja Pada Masa Pandemi COVID-19, dalam kondisi pandemi COVID-19 ini pengurus perusahaan/pengusaha perlu melakukan berbagai upaya pencegahan penularan infeksi di tempat kerja agar dapat mempertahankan kegiatan usaha dengan mengikutsertakan tenaga kerja secara aktif (Yuantari, 2021). Pemerintah menghimbau agar setiap instansi perusahaan/pengusaha salah satunya instansi kesehatan untuk dapat membuat dan menerapkan Standar Operasional Prosedur (SOP) Keselamatann dan Kesehatan Kerja (K3) selama pandemi COVID-19 dalam bentuk upaya pencegahan terpaparnya dari virus tersebut.

Penulis telah melakukan survei pada salah satu Klinik Pratama di Kota Bandung tentang bagaimana Standar Operasional Prosedur (SOP) Keselamatann dan Kesehatan Kerja (K3) yang dibuat selama pandemi COVID-19 dalam upaya pencegahan terpaparnya virus COVID-19 pada tenaga kesehatan yang bekerja pada Klinik tersebut. Berikut ialah Standar Operasional Prosedur (SOP) Keselamatann dan Kesehatan Kerja (K3) selama pandemi COVID-19 di Klinik Pratama Green Care Kota Bandung.

Tabel 1. Standar Operasional Prosedur (SOP) Keselamatann dan Kesehatan Kerja (K3) Pandemi COVID-19

SOP Keselamatann dan Kesehatan Kerja (K3) Pandemi COVID-19

\begin{tabular}{cccc}
\cline { 2 - 4 } Klinik Pratama & \multicolumn{2}{c}{ No. Protap : } & \multicolumn{2}{c}{ DIVISI PELAYANAN KLINIK } \\
\cline { 2 - 4 } Green Care & $\begin{array}{c}\text { 003/PK/GCMC /VI/13 } \\
\text { Tgl diberlakukan: } \\
\text { 03/03/2020 }\end{array}$ & No. Revisi : - & Hal : 1 / 2 \\
\hline
\end{tabular}




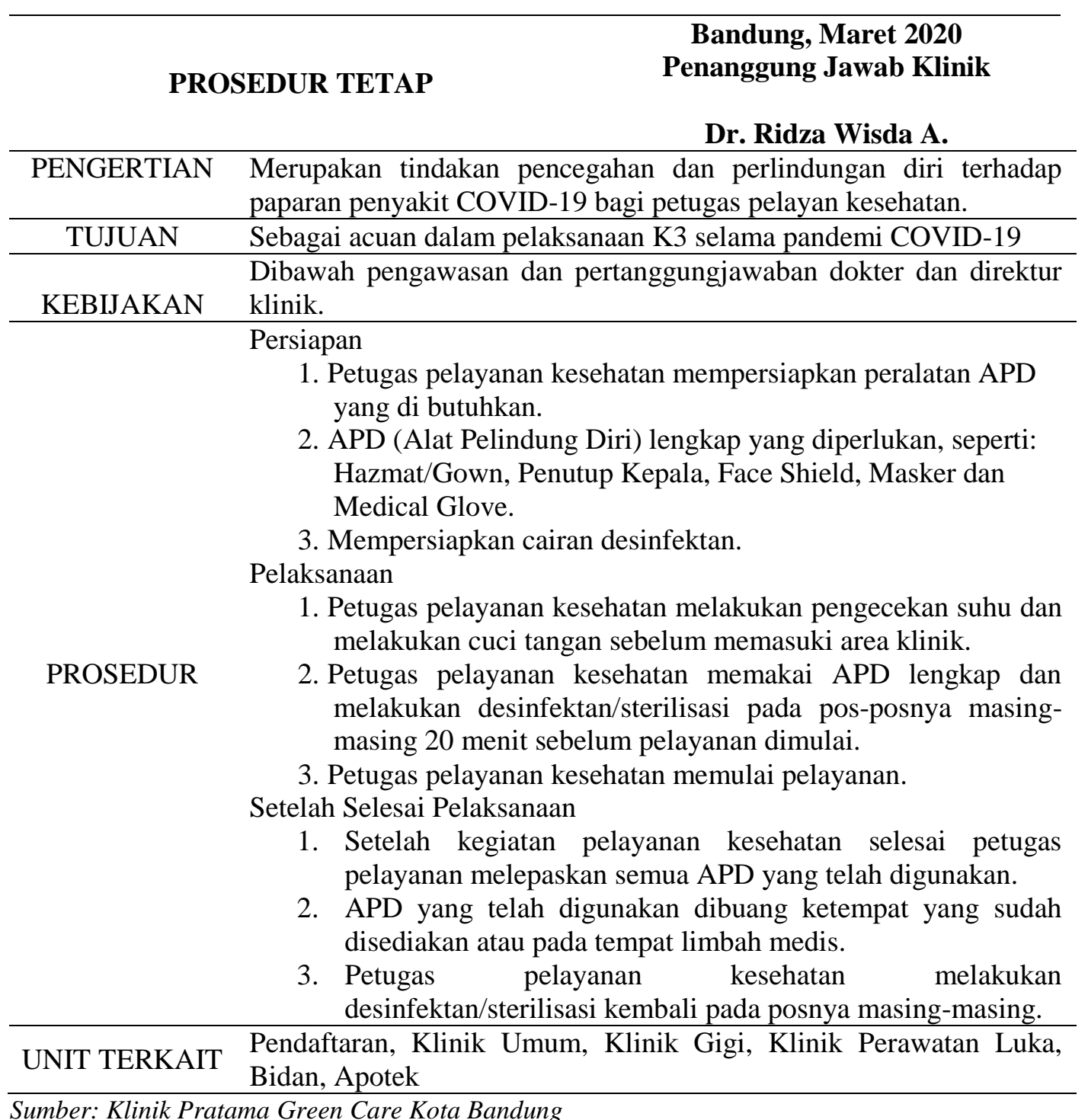

Sumber: Klinik Pratama Green Care Kota Bandung

Berdasarkan tabel 1 di atas hasil survei tersebut penulis akan melakukan penelitian dengan judul "Analisis Pelaksanaan Keselamatann dan Kesehatan Kerja (K3) di bagian Pendaftaran Klinik Pratama Green Care Kota Bandung di Masa Pandemi COVID-19“. Tujuan utama penelitian ini adalah untuk mengetahui kepatuhan pegawai rekam medis bagian pendaftaran di Klinik Pratama Green Care Kota Bandung terhadap penerapan Standar Operasional Prosedur (SOP) Keselamatann dan Kesehatan Kerja (K3), tujuan khususnya adalah mengidentifikasi Standar Operasional Prosedur (SOP) terkait Keselamatann dan Kesehatan Kerja (K3) di bagian pendaftaran Klinik Pratama Green Care Kota Bandung dan mengidentifikasi faktor manusia (petugas rekam medis) di bagian pendaftaran Klinik Pratama Green Care Kota Bandung.

\section{METODE PENELITIAN}

Jenis penelitian yang digunakan dalam penelitian ini adalah metode kualitatif dengan pendekatan deskriptif (Sugiyono, 2014). Subjek penelitian yang digunakan dalam penelitian ini adalah 2 petugas pendaftaran di Klinik Pratama Green Care Kota Bandung. Dalam memilih subjek penelitian, penelitian menggunakan teknik sampling purposive. 
Sampling purposive merupakan "teknik penentuan sampel dengan pertimbangan tertentu". Pemilihan subjek tersebut dilatarbelakangi karena tujuan dari penelitian ini yaitu bagaimana pelaksanaan Standar Operasional Prosedur (SOP) Keselamatann dan Kesehatan Kerja (K3) di Klinik Pratama Green Care Kota Bandung serta untuk mengetahui kepatuhan pegawai rekam medis bagian pendaftaran di Klinik Pratama Green Care Kota Bandung terhadap penerapan Standar Operasional Prosedur (SOP) Keselamatann dan Kesehatan Kerja (K3).

Instrumen yang baik akan menghasilkan data yang baik pula. Instrumen yang digunakan dalam penelitian ini berupa pedoman angket atau kuesioner dan wawancara, yang diberikan kepada petugas pendaftaran Klinik Pratama Green Care Kota Bandung. Teknik pengumpulan data yang digunakan dalam penelitian ini adalah berupa angket atau kuesioner dan wawancara, Jenis angket yang digunakan dalam penelitian ini adalah angket terbuka. Angket terbuka merupakan angket yang berisi pertanyaan atau pernyataan yang dapat diisi bebas oleh responden. Jenis wawancara yang digunakan dalam penelitian ini berupa wawancara semiterstruktur. Teknik analisis data yang digunakan peneliti merupakan teknik analisis Miles and Huberman.

\section{HASIL DAN PEMBAHASAN}

\section{A. Hasil Penelitian}

Berdasarkan hasil penelitian didapat dari angket terbuka dan wawancara semi struktur yang dilakukan secara daring. Angket disebarkan secara daring melalui google form, sedangkan untuk wawancara dilakukan menggunakan whatsapp. Adapun hasil penelitian yang diperoleh dalam penelitian ini adalah sebagai berikut.

Tabel 2. Check list Peralatan Keselamatann dan Kesehatan Kerja

\begin{tabular}{|c|c|c|c|c|c|c|}
\hline \multirow[t]{2}{*}{ No. } & \multirow[t]{2}{*}{ Jenis Pekerjaan } & \multicolumn{2}{|c|}{$\begin{array}{l}\text { Apd Yang } \\
\text { Diberikan } \\
\text { Perusahaan }\end{array}$} & \multicolumn{2}{|c|}{$\begin{array}{c}\text { APD Yang } \\
\text { Dipakai Pekerja }\end{array}$} & \multirow[t]{2}{*}{ Keterangan } \\
\hline & & Ya & Tidak & Ya & Tidak & \\
\hline 1. & Face Shield & $\sqrt{ }$ & & $\sqrt{ }$ & & di Pakai Pekerja \\
\hline 2. & Hazmat/Gown & $\sqrt{ }$ & & $\sqrt{ }$ & & di Pakai Pekerja \\
\hline 3. & $\begin{array}{l}\text { Head } \\
\text { Cap/Pelindung } \\
\text { Kepala }\end{array}$ & $\sqrt{ }$ & & $\sqrt{ }$ & & di Pakai Pekerja \\
\hline 4. & Masker Medis & $\sqrt{ }$ & & & - & $50 \%$ \\
\hline 5. & Medical Gloves & $\sqrt{ }$ & & $\sqrt{ }$ & & di Pakai Pekerja \\
\hline
\end{tabular}

1. Angket

Angket disebarkan kepada seluruh petugas pendaftaran di Klinik Pratama Green Care Kota Bandung. Angket yang digunakan dalam penelitian ini merupakan jenis angket terbuka. Berikut ini merupakan jawaban yang diberikan oleh responden.

a. Apakah Bapak/Ibu mengetahui atau memahami SOP K3 di masa pandemi COVID-19 yang berlaku di klinik ? Bagaimana menurut bapak / ibu terkait SOP K3 yang berlaku apakah sudah sesuai dengan aturan yang ada ?

"Iya, sudah mengetahui dan sudah sesuai dengan SOP K3 yang diterapkan di Klinik" 
b. Apakah ada pelatihan dan pendidikan untuk mengetahui atau memahami bagaimana pelaksanaan SOP K3 yang benar di klinik? Menurut bapak / ibu apakah di perlukan untuk pelatihan dan pendidikan?

"Di klinik tidak diadakan pelatihan atau pendidikan, namun lebih ke arah sosialisasi ke seluruh karyawan untuk memahami SOP K3 yang dibuat oleh klinik"

c. Apakah bapak/ibu sudah menjalankan seluruh SOP K3 yang berlaku di Klinik? Bagaimana menurut bapak / ibu SOP K3 jika tidak di jalankan dengan baik selama masa pandemi COVID-19?

"Sudah dijalankan ,seperti menggunakan APD (Alat Pelindung Diri) seperti: Hazmat/Gown, Penutup Kepala, , Masker dan Medical Glove. Jika tidak digunakan maka akan rentan tertular dan beresiko juga menularkan kepada nakes lainnya bahkan kepada pasien. Mengingat pelayanan kesehatan adalah sarana umum yang saat pandemi seperti sekarang dibutuhkan oleh masyarakat, maka akan terjadi hambatan untuk pelayanan kesehatan jika nakesnya tidak menggunakan APD atau tidak mematuhi SOP K3"

d. Adakah kejadian kecelakaan terkait Keselamatann dan Kesehatan Kerja (K3) di klinik di masa pandemi COVID-19? Bagaimana penanganan klinik menurut bapak / ibu, apakah sudah sesuai dengan SOP K3 yang berlaku?

"Ada salah satu petugas pendaftaran yang terpapar COVID-19. Karena tidak memakai APD dengan benar, Dan untuk penanganan dari klinik sendiri sudah baik dan benar. di saat ada petugas yang mengalami gejala disarankan untuk swab antigen. jika hasil positif di sarankan untuk soman. dan setelah selesai soman petugas itu dilakukan swab ulang jika hasil masih positif soman di lanjut sesuai waktu yang ditentukan, jika hasil negatif petugas bisa beraktifitas kembali seperti biasa "

\section{Wawancara}

Wawancara yang digunakan dalam penelitian ini adalah jenis wawancara semi terstruktur terhadap salah satu petugas pendaftaran di Klinik Pratama Green Care Kota Bandung. Wawancara dilakukan dengan tujuan memperdalam data yang diperoleh dari angket. Adapun hasil wawancara yang telah dilakukan adalah sebagai berikut.

a. Bapak/Ibu mengetahui atau memahami SOP K3 di masa pandemi COVID19 yang berlaku di klinik? Bagaimana menurut bapak / ibu SOP K3 yang berlaku apakah sudah sesuai dengan aturan yang ada?

"Saya mengetahui dan memahami SOP K3 yang berlaku di klinik, menurut saya SOP K3 di Klinik dan sudah sesuai dengan KEPUTUSAN MENTERI KESEHATAN REPUBLIK INDONESIA NOMOR HK.01.07/MENKES/413/ 2020 TENTANG PEDOMAN PENCEGAHAN DAN PENGENDALIAN CORONAVIRUS DISEASE 2019 (COVID-19)" (Handayani, Hadi, Isbaniah, Burhan, \& Agustin, 2020).

b. Apakah ada pelatihan dan pendidikan untuk mengetahui atau memahami bagaimana pelaksanaan SOP K3 yang benar di klinik? Menurut bapak / ibu apakah diperlukan untuk pelatihan dan pendidikan?

"Tidak ada Pelatihan dan pendidikan terkait penerapan SOP K3. Namun, sebelum melakukan penerapan SOP K3 Klinik mengadakan sosialisasi dan pelatihan terkait SOP K3 yang berlaku sesuai dengan keputusan kepmenkes agar setiap petugas pelayanan kesehatan dapat mengerti dan memahami bagaimana cara mengimplementasikan dengan baik dan benar untuk menjalankan SOP tersebut. Sebenarnya pelatihan dan pendidikan terkait 
SOP K3 diperlukan agar menjadi acuan dan arahan bagi setiap petugas pelayanan kesehatan guna menunjang kegiatan pelayanan yang baik dan prima terutama agar terhindarnya para petugas pelayanan dari terpaparnya COVID-19".

c. Apakah bapak/ibu sudah menjalankan seluruh SOP K3 yang berlaku di Klinik? Bagaimana menurut bapak / ibu SOP K3 Jika tidak di jalankan dengan baik selama masa pandemic COVID-19?

"Saya masih perlu beradaptasi dengan kebiasaan baru akibat dari pandemi COVID-19 ini, sehingga saya pun masih mempelajari dengan cermat SOP K3 yang berlaku di Klinik agar dapat terselenggara dengan baik sesuai dengan prosedur yang seharusnya, menurut saya jika SOP K3 ini tidak dijalankan dengan baik atau tidak dijalankan sesuai prosedur maka pencegahan terpaparnya COVID-19 terhadap para pegawai pelayanan kesehatan tidak akan terealisasi kan, yang nantinya akan tetap ada petugas pelayanan yang terpapar COVID-19”.

d. Adakah kejadian kecelakaan Keselamatan dan Kesehatan Kerja (K3) di klinik di masa pandemic COVID-19? Bagaimana penanganan klinik menurut bapak / ibu, apakah sudah sesuai dengan SOP K3 yang berlaku?

"Ada 1 petugas pelayanan di bagian rekam medis pendaftaran rawat jalan yang terpapar COVID-19 dikarenakan petugas tersebut tidak menggunakan medical gloves selama pelayanan berlangsung, petugas pelayanan tersebut tidak menggunakan medical gloves selama 3 hari dikarenakan masih perlu beradaptasi dengan SOP K3 yang diterapkan sehingga beliau masih dikatakan malas untuk mematuhi prosedur dari SOP K3 tersebut. penanganan yang dilakukan oleh klinik terhadap setiap petugas pelayanan yang terpapar COVID-19 ialah;

1) Petugas yang memiliki gejala seperti demam, flu, batuk, sakit tenggorokan, mual, muntah, diare, sakit kepala dan lemas selama 3 hari disarankan swab antigen

2) Jika hasil positif petugas diberikan obat sesuai dengan simptom yang dirasakan dan ditambahkan multivitamin dan melakukan isolasi mandiri sampai batas waktu yang telah ditentukan

3) Menelusuri riwayat kontak/bertemu, dengan orang yang ditemui oleh petugas yang terpapar dan melakukan swab antigen meskipun tidak mengalami simptom, jika hasilnya negatif orang tersebut tetap harus melakukan soman sampai batas yang telah ditentukan

4) Jika waktu soman telah berakhir petugas yang terpapar COVID-19 tersebut melakukan swab antigen kembali, jika hasilnya masih positif petugas tersebut melakukan soman kembali sampai batas waktu yang telah ditentukan, namun jika hasilnya negatif maka petugas dapat kembali bekerja.

\section{B. Pembahasan}

Standar Operasional Prosedur (SOP) terkait Keselamatann dan Kesehatan Kerja (K3) di bagian pendaftaran Klinik Pratama Green Care Kota Bandung merupakan tindakan pencegahan dan perlindungan diri terhadap paparan penyakit COVID-19 bagi petugas pelayan kesehatan. Mulai dari:

1. Petugas menyiapkan peralatan APD seperti Hazmat/Gown, Penutup Kepala, Face Shield, Masker dan Medical Glove.dan cairan desinfektan.

2. Melakukan pengecekan suhu dan mencuci tangan sebelum memasuki area klinik 
3. Petugas menggunakan APD lengkap dan melakukan desinfektan/sterilisasi pada posposnya masing-masing 20 menit sebelum pelayanan dimulai.

4. Jika kegiatan pelayanan kesehatan selesai petugas pelayanan melepaskan semua APD yang telah digunakan dan APD yang telah digunakan dibuang ketempat yang sudah disediakan atau pada tempat limbah medis.

Selama pelaksanaan K3 di unit rekam medis khususnya bagian pendaftaran Klinik Pratama Green Care Kota Bandung sudah berjalan dengan baik. Tapi masih ada salah satu petugas yang kurang disiplin seperti yang terdapat pada Tabel 2. terkait penggunaan APD pada setiap perkerja dalam pelaksanaan nya. Pada tabel tersebut terdapat pekerja yang tidak menggunakan medical gloves dalam pelaksanaan pelayanan pendaftaran yang dimana dapat berpotensi akan terpaparnya COVID-19. Adapun SOP K3 yang berlaku di Klinik Pratama Green Care Kota Bandung di masa pandemi COVID-19, semua petugas pendaftaran sudah mengetahui dan memahami dengan baik. Meskipun dari pihak manajemen hanya melakukan sosialisasi pelaksanaan SOP K3 yang benar dan tidak diadakannya pelatihan dan pendidikan. Hal ini sejalan dengan penelitian (Triningtyas, 2021) yang menyatakan pentingnya pengetahuan dan sikap tenaga kesehatan tentang alat pelindung diri pada era COVID-19. Adapun alur penanganan keselamatann dan kesehatan kerja sudah ada dan terlaksana dengan baik.di saat salah satu petugas terpapar penyakit.

\section{KESIMPULAN}

Berdasarkan Penelitian yang dilakukan oleh penulis, maka di temukan berbagai masalah diantara nya kurang disiplinnya Petugas Pendaftaran dalam Pelaksanaan SOP K3 di masa pandemic, kurangnya pengawasan dari manajemen dalam pelaksanaan SOP K3 di masa pandemic, belum ada nya pelatihan dan pendidikan dalam pelaksanaan SOP K3 yang terbaru. Dari hasil di atas penulis dapat menyimpulkan bahwa Klinik Pratama Green Care Kota Bandung dalam pelaksanaan SOP K3 di masa pandemi sudah berjalan dengan baik. Namun untuk petugas nya kurang disiplin dalam melaksanakan SOP K3. Dikarenakan kurang pengawasan dari pihak manajemen klinik.

\section{BIBLIOGRAFI}

Anizar, Ir, \& Kes, M. (2009). Teknik Keselamatan dan Kesehatan Kerja di Industri. Yogyakarta: Graha Ilmu.

Djatmiko, Riswan Dwi. (2016). Keselamatan dan kesehatan kerja. Deepublish.

Handayani, Diah, Hadi, Dwi Rendra, Isbaniah, Fathiyah, Burhan, Erlina, \& Agustin, Heidy. (2020). Coronavirus disease 2019. Jurnal Respirologi Indonesia, 40(2), 119-129.

Irwansyah, Muhammad, Lady, Lovely, \& Umiyati, Ani. (2017). Pengendalian Risiko Kecelakaan Kerja pada Proses Bongkar Muat Produk dengan Pendekatan HIRA (Studi Kasus di PT. XYZ). Jurnal Teknik Industri Untirta.

Ivana, Azza, Widjasena, Baju, \& Jayanti, Siswi. (2014). Analisa Komitmen Manajemen Rumah Sakit (RS) Terhadap Keselamatan Dan Kesehatan Kerja (K3) Pada RS Prima Medika Pemalang. Jurnal Kesehatan Masyarakat (Undip), 2(1), 35-41.

Korompot, Salim. (2020). Peran Bimbingan dan Konseling dalam Penanganan Pandemi COVID 19. Prosiding Seminar Bimbingan Dan Konseling, 80-86.

Lai, Chih Cheng, Shih, Tzu Ping, Ko, Wen Chien, Tang, Hung Jen, \& Hsueh, Po Ren. (2020). Severe acute respiratory syndrome coronavirus 2 (SARS-CoV-2) and coronavirus disease-2019 (COVID-19): The epidemic and the challenges. International Journal of Antimicrobial Agents, 55(3), 105924.

Menkes, R. I. (2008). Peraturan Menteri Kesehatan Republik Indonesia No. 
269/MenKes/Per/III/2008 tentang Rekam Medis. Jakarta: Kementerian Kesehatan $R I$.

Menkes, R. I. (2011). Peraturan Menteri Kesehatan Republik Indonesia No. 028/MenKes/Per/I/2011 tentang Klinik. Jakarta: Kementrian Kesehatan RI.

Mukti, Ilman, Noerpaiz, Yoga Fikri Noerpaiz, \& Wahab, Syaikhul Wahab. (2021). Analisis Pelaksanaan Keselamatan Dan Kesehatan Kerja Dibagian Filling Rekam Medis RS X. Cerdika: Jurnal Ilmiah Indonesia, 1(8), 980-987.

Nugrahanto, Dionza Surya. (2018). Pembuatan Sistem Informasi Pelayanan Kesehatan Masyarakat Berbasis Web Mapping (Studi Kasus: Kabupaten Sukoharjo, Provinsi Jawa Tengah). ITN MALANG.

Respati, Titik, \& Rathomi, Hilmi Sulaiman. (2020). Bunga Rampai Artikel Penyakit Virus Korona (COVID-19). Jl. Purnawarman, (63).

Salawati, Liza. (2015). Penyakit akibat kerja dan pencegahan. Jurnal Kedokteran Syiah Kuala, 15(2), 91-95.

Sugiyono. (2014). Metode Penelitian Kuantitatif Kualitatif Dan R\&D (12th, Cetaka ed.). Bandung: CV Alfabeta.

Triningtyas, Anastasia Yani, Nurlaela, Lutfhi, Juliastuti, Henny, \& Pradini, Astri. (2021). Pengetahuan dan Sikap Tenaga Kesehatan di 13 Puskesmas Kota Cimahi Tentang Penggunaan Alat Pelindung Diri Pada Era COVID-19.

Yuantari, Maria Goretti Catur, Rachmani, Enny, Rimawati, Eti, Handayani, Sri, \& Kusuma, Edi Jaya. (2021). Analysis of Health Protocol Application to Compliance Level In Informal Workers During the COVID-19 Pandemic. VISIKES: Jurnal Kesehatan Masyarakat, 20(1).

(C) 2021 by the authors. Submitted for possible open access publication under the terms and conditions of the Creative Commons Attribution (CC BY SA) license (https://creativecommons.org/licenses/by-sa/4.0/). 